\title{
BLOOD PRESSURE REDUCTION ON ELDERLY WITH HYPERTENSION WITH CELERY PRODUCTS IN PEKALONGAN CITY
}

\author{
Ni'matul Ulya ${ }^{1)}$, Miftachul Jannah ${ }^{2)}$ \\ Email : renex_cubby@yahoo.co.id \\ ${ }^{1,2}$ Akademi Kebidanan Harapan Ibu Pekalongan \\ Jl. Sriwijaya No 7 Pekalongan
}

Article Information

Received:

August 16, 2019

Revised:

December 23, 2019

Accepted:

January 19, 2020

Available online:

January 23, 2020

\begin{abstract}
Elderly is an ageing process where age reaches more than 60 years. Hypertension is a state of increased systolic blood pressure more than equal to $140 \mathrm{mmHg}$ and $90 \mathrm{mmHg}$ for diastolic on two measurements with an interval of five minutes in a state of sufficient rest/calm. The study purpose was to determine the effectiveness of celery products on the reduction of blood pressure in the elderly with hypertension. Design of this study was quasiexperimental. The population of this study was elderly with hypertension; the sample was taken using a multistage random sampling technique and obtained 15 people per group. The results showed that the characteristics of respondents based on gender were mostly female was 22 respondents $(73.3 \%)$. While the characteristics of respondents based on age were mostly between the ages of 60 - 65 years were 16 respondents (53.3\%). The results of systolic blood pressure measurement in elderly hypertension given celery leaf extract were higher at an average of $28.33 \mathrm{mmHg}$ compared to those given simplicia of celery leaf, which was an average of $22.67 \mathrm{mmHg}$. The results of measurements of diastolic blood pressure reduction respondents who were given celery leaf extract were higher at an average of $18 \mathrm{mmHg}$ compared to those given simplicia of celery leaf, which was on average $12.3 \mathrm{mmHg}$. There are differences in the average pre and post diastolic pressure in elderly with hypertension who were given simplicia and celery leaf extract. There is no difference in systolic and diastolic blood pressure reduction between those given simplicia and celery leaf extract.
\end{abstract}

Keywords: Elderly, Hypertension, Celery

\section{Introduction}

Elderly is the process of getting older when age reaching 60 years and over. Hypertension is a state of increased systolic blood pressure more than equal to $140 \mathrm{mmHg}$ and diastolic more than equal to $90 \mathrm{mmHg}$ on two measurements with an interval of five minutes in a state of sufficient rest/calm. ${ }^{[1]}$ Based on the prevalence of elderly with hypertension in Indonesia, there were $45.9 \%$ for ages 55 64 years, $57.6 \%$ aged $65-74$ years and $63.8 \%$ aged $>75$ years. ${ }^{[2]}$ Data from the
Central Java Provincial Health Office in 2016, of the eleven types of noncommunicable diseases, hypertension was the most common disease suffered by the people of Central Java with a proportion of $55 \% .{ }^{[3]}$ Whereas in Pekalongan City, non-communicable diseases such as hypertension occupy the first rank of the most common disease suffered by residents. Data from the Pekalongan City Health Office shows that the number of hypertension in 2016 has 
reached six thousand patients. ${ }^{[4]}$ People with hypertension often receive pharmacological therapy, which is a form of treatment given by a doctor. In addition to pharmacological therapy, nonpharmacological therapy can also be given or better known as herbal therapy which is an excellent choice for hypertension patients as a study conducted by Intan Damaya. ${ }^{[5]}$ on the Effectiveness of Cucumber and Celery Leaves as Non-pharmacological Therapy in Hypertension. Celery (Apium Graveolens $L$ ) is one of herbal therapy to treat hypertension. People in China have long used celery to prevent blood vessel constriction and high blood pressure. Celery contains apigenin which is very useful for preventing narrowing of blood vessels and high blood pressure. ${ }^{[6]}$ The novelty in this study compares celery products in the form of simplicia and celery extract to decrease blood pressure in older adults with hypertension which has never been studied before. The study purpose was to determine the effectiveness of celery products on reducting blood pressure on elderly with hypertension in Pekalongan City.

\section{Method}

The study design was quasi-experimental study design that has a control group but cannot control the variables from outside that affect the implementation of the experiment entirely. The population in this study was elderly who suffer from hypertension in Pekalongan city. The sample was taken using a multistage random sampling technique and obtained 15 people per group. Data were collected using a mercury Tensimeter, a stethoscope and an observation sheet. Univariate analysis in this study used to determine the characteristics based on gender and age of respondents. Analyze the reduction of blood pressure using a paired t-test with pre-test and post-test design. Before conducting a statistical test, the data was to analyze the normality. The data with normal distribution were analyzed using Mann Whitney, and the data which had not a normal distribution were analyzed using the Wilcoxon nonparametric statistical test.

\section{Result and Discussion}

a. Univariate Analysis

1) Gender

Table 1 Respondents Characteristic Based on gender

\begin{tabular}{ccc}
\hline Gender & $\mathbf{f}$ & $\mathbf{( \% )}$ \\
\hline Male & 8 & 26.7 \\
Female & 22 & 73.3 \\
\hline Total & 30 & 100 \\
\hline
\end{tabular}

Based on table 1, the characteristics of respondents by gender showed a small proportion of respondents were male $26.7 \%$ (eight respondents), and the majority of respondents were female $73.3 \%$ (22 respondents).

Jajuk on her study [7] concerning the Relationship of Gender with the Intensity of Hypertension in the Elderly in the Work Area of the Lakbok Health Center in Ciamis Regency showed that female had more possibility suffering hypertension than male. Yuliarti also ${ }^{[8]}$ stated that there was a significant relationship between gender and the incidence of hypertension. It shows that estrogen hormone levels influence the incidence of hypertension in women. When the women reached older age, the hormone estrogen decreases, so they vulnerable to hypertension.

2) Age

Table 2 Respondents Characteristic Based on Age

\begin{tabular}{lcc}
\hline \multicolumn{1}{c}{ Age (years old) } & f & $\mathbf{( \% )}$ \\
\hline $60-65$ & 16 & 53.3 \\
$66-70$ & 7 & 23.3 \\
$71-75$ & 4 & 13.3 \\
$>75$ & 3 & 10 \\
\hline$\quad$ Total & 30 & 100 \\
\hline
\end{tabular}

Based on Table 2, most of the respondents were at the ages of $60-65$ years $(53.3 \%)$, and a small 
portion was respondents at the age more than 75 years old (10\%).

A study about the relationship of characteristics (age, sex, level of education) and physical activity with blood pressure in the elderly in the village of Makam Haji in Kartasura subdistrict, Sukoharjo district showed that there was no relationship between age and systolic and diastolic. Hypertension could occur caused other factors that directly affect blood pressure, such as food intake. ${ }^{[9]}$

b. Bivariate Analysis

1) Differences in Pre and Post Systolic Blood Pressure Reduction in the Elderly with Hypertension given Simplicia and Celery Leaf Extract in Pekalongan City

Table 3 Pre and Post Systolic blood pressure in the elderly with hypertension given Simplicia and Celery Leaf Extract in Pekalongan City

\begin{tabular}{lcc}
\hline \multicolumn{1}{c}{ BP } & Mean & p-value \\
\hline Systolic Pre-Simplicia & 156.0 & 0 \\
Systolic Post-Simplicia & 132.67 & 0.001 \\
\hline Systolic Pre-Extract & 99.33 & 0.005 \\
Systolic Post-Extract & 87.00 & \\
\hline
\end{tabular}

Table 3 shows that giving simplicia to respondents was obtained p-value $0.001<0.05$, which means there are differences in the average systolic pressure of pre and post-test in elderly with hypertension given simplicia of celery leaf. While the Wilcoxon test results in respondents who given celery leaf extract obtained p-value $0.005<0.05$, which means there are differences in the average systolic pressure of pre and post in elderly with hypertension who were given celery leaf extract. .

Systolic blood pressure is created due to the contraction of the heart that pushes blood through arteries throughout the body ${ }^{[10]}$
Apigenin in celery products could reduce systolic blood pressure. Apigenin has functioned as a betablocker which can slow the heart rate and reduce the strength of heart contractions so that blood could flow less and blood pressure becomes reduced..$^{[11]}$

2) Differences in Pre and Post Diastolic Blood Pressure Reduction in the Elderly with Hypertension given Simplicia and Celery Leaf Extract in Pekalongan City

Table 4 Pre and Post Diastolic blood pressure in the elderly with hypertension given Simplicia and Celery Leaf Extract in Pekalongan City

\begin{tabular}{lcc}
\hline \multicolumn{1}{c}{ BP } & Mean & p-value \\
\hline Diastolic Pre Simplisia & 160.0 & 0.001 \\
Diastolic Post Simplisia & 131.7 & \\
\hline Diastolic Pre Ekstrak & 103.3 & 0.001 \\
Diastolic Post Ekstrak & 85.3 & \\
\hline
\end{tabular}

Table 4 shows the Wilcoxon test results in elderly with hypertension before and after given simplicia of celery leaf and obtained p-value $0.001<0.05$, which means there are differences in the average pre and post diastolic pressure in elderly hypertension given simplicia of celery leaves. While the Wilcoxon test results in blood pressure before and after given celery leaf extract, obtained p-value $0.001<0.05$, which means there are differences in the average pre and post diastolic pressure in elderly hypertension given celery leaf extract.

Diastolic blood pressure was measured when the heart relaxes, and it made blood vessels to widen so that blood can flow smoothly to the heart's ventricles. ${ }^{[10]}$ According to Triola's study about Efficacy of Celery Leaves Against High Blood Pressure in Hypercholesterolemia Patients states that apigenin work 
by relaxing the muscles so when the heart relaxes, it can facilitate blood to flow to the heart.

3) The Difference between Systolic and Diastolic Blood Pressure Reduction after Given Simplisia and Celery Leaf Extract

Table 5 The Difference between Systolic and Diastolic Blood Pressure Reduction after Given Simplisia and Celery Leaf Extract

\begin{tabular}{clc}
\hline $\begin{array}{c}\text { BD } \\
\text { Reduction }\end{array}$ & \multicolumn{1}{c}{ Group } & $\begin{array}{c}\boldsymbol{p} \text { - } \\
\text { value }\end{array}$ \\
\hline \multirow{3}{*}{ Systolic } & $\begin{array}{l}\text { Simplicia ofCelery } \\
\text { Leaf } \\
\text { Celery Leaf Extract }\end{array}$ & 0.323 \\
\hline \multirow{3}{*}{ Diatolic } & $\begin{array}{l}\text { Simplicia of Celery } \\
\text { Leaf } \\
\end{array}$ & 0.721 \\
& Celery Leaf Extract & \\
\hline
\end{tabular}

From table 5 shows a decrease in systolic and diastolic blood pressure showed from $\mathrm{p}$ value $>0.05$, which means there is no difference in systolic and diastolic blood pressure reduction between those given simplicia and celery leaf extract.

According to Dalimartha, the chemical ingredients of celery herbs are flavonoids, saponins, tannins $1 \%$, essential oils $0.033 \%$, flavour-glucosides (apiin), apigenin, choline, lipase, asparagines, bitter substances, vitamins (A, B, and C). Every 100 $\mathrm{g}$ of celery herb contains $93 \mathrm{ml}$ of water, $0.9 \mathrm{~g}$ protein, $0.1 \mathrm{~g}$ fat, $4 \mathrm{~g}$ carbohydrates, $0.9 \mathrm{~g}$ fibre, $50 \mathrm{mg}$ calcium, $1 \mathrm{mg}$ iron, $40 \mathrm{mg}$ phosphorus, $150 \mathrm{mg}$ iodine, potassium $400 \mathrm{mg}$, magnesium 85 $\mathrm{mg}$, vitamin A $130 \mathrm{IU}$, vitamin C $15 \mathrm{mg}$, riboflavin $0.05 \mathrm{mg}$, thiamine $0.03 \quad \mathrm{mg}$, and nicotinamide $0.4 \mathrm{mg}$. The root contains asparagine, manite, starch, lenders, essential oils, pentosan, glutamine, and tyrosine. The seeds contain apiin, evaporated oil, apigenin, and alkaloids; and apigenin has hypotensive properties. $^{[11]}$

The solubility of the substance used for simplicia or extract will increase if the preparation process was done at a temperature and drying inopportune time. ${ }^{[12]}$

The results of this study can be concluded that celery extract was faster in reducing systolic and diastolic blood pressure in the elderly with hypertension due to the extraction process in the evaporation using $70^{\circ} \mathrm{C}$, this is in accordance to Daryonno's study. The solubility of substances would change significantly if the preparation process were carried out at a temperature and drying inopportune time, and Astuti state that in the process of evaporation can cause changes in the physical and chemical properties of the material and a decrease in food quality.

\section{Conclusion}

Based on the discussion above it can be concluded that the systolic pressure reduction in elderly with hypertension was higher by giving celery leaves extract, decreasing about $28.33 \mathrm{mmHg}$, than by giving simplicia of celery leaves, decrease about $22.67 \mathrm{mmHg}$. Moreover, for diastolic pressure reduction higher by giving celery leaves extract, decrease about $18 \mathrm{mmHg}$, than by giving simplicia of celery leaves, decrease about 12.3 mmHg. Statistically, there were no differences in systolic and diastolic reduction between simplicia or extract of celery leaves.

This study showed that there was an alternative therapy using nonpharmacological therapy to reducing hypertension in the elderly by using celery. There were need to do further study to complement this study by adding variables that can affect blood pressure such as eating habit, nutrition, stress level and activities. 


\section{Acknowledgement}

Authors would like to thank The Ministry Of Research, Technology and Higher Education for funding this study. Our gratitude to the Head of Sanctification and Herbal Medicine Services Centre of Pekalongan City for providing opportunities and assisting us in making celery extracts and simplicia. Our gratitude for all respondents for sparing the time for this study

\section{References}

[1] Sidabutar RP, W.P. Hipertensi Esensial. Jakarta: Balai Penerbit FK-UI. 2009

[2] Kemenkes RI. Gambaran Kesehatan Lanjut Usia di Indonesia. Jakarta: Kementerian Kesehatan Republik Indonesia. 2013.

[3] Dinas Kesehatan Jawa Tengah. Buku Profil Kesehatan Provinsi Jawa Tengah. Semarang: Dinkes Jateng. 2017.

[4] Dinas Kesehatan Kota pekalongan. Angka Kejadian Hipertensi di Kota Pekalongan.Pekalongan. 2017.

[5] Antika, Intan D \& Mayasari, D. 2016. Efektivitas Mentimun Sebagai Terapi NonFarmakologis Pada Hipertensi. Majority. 2016. Volume 5 Nomor 5.

[6] Trinoval, YN. Pengaruh Pemberian Rebusan Seledri Terhadap Penurunan Tekanan Darah Pada Penderita Hipertensi Di Kelurahan Sidanegara Kecamatan Cilacap Tengah (Skripsi).2010.

[7] Jajuk Kusumawati, dkk. Hubungan Jenis Kelamin dengan Intensitas Hipertensi pada Lansia di Wilayah Kerja Puskesmas Lakbok Kabupaten Ciamis. Ciamis: Mutiara Medika. 2016. Vol. 16 No. 2: 46-51.

[8] Yuliarti. Mayo Clinic Hipertensi, Mengatasi Tekanan Darah
Tinggi. Jakarta: PT Intisari Mediatama. 2007.

[9] Novitaningtyas, T. Hubungan karakteristik (umur, jenis kelamin, tingkat pendidikan) dan aktivitas fisik dengan tekanan darah pada lansia di kelurahan makam haji kecamatan kartasura kabupaten sukoharjo. Skripsi. Program Studi Ilmu Gizi Fakultas Ilmu Kesehatan Universitas Muhammadiyah Surakarta. 2014.

[10] Rochimah, dkk. Keterampilan Dasar Praktek Klinik. Jakarta: TIM. 2011.

[11] Triola Fitria dan Oktadoni Saputra. Khasiat Daun Seledri Terhadap Tekanan Darah Tinggi Pada Pasien Hiperkolesterolemia. Skripsi. Fakultas Kedokteran Universitas Lampung. 2016.

[12] Dalimartha, S. Care Your self Hipertension.Penebar Plus : Jakarta. 2008. 